University of Nebraska - Lincoln

DigitalCommons@University of Nebraska - Lincoln

USDA Forest Service / UNL Faculty Publications U.S. Department of Agriculture: Forest Service -National Agroforestry Center

2013

\title{
Interpretation of gypsy moth frontal advance using meteorology in a conditional algorithm
}

\author{
K. L. Frank \\ Applied Climatologists, Inc., klfrank@live.com \\ P. C. Tobin \\ USDA Forest Service, pctobin@uw.edu \\ H. W. Thistle Jr. \\ USDA Forest Service \\ Laurence S. Kalkstein \\ University of Miami
}

Follow this and additional works at: https://digitalcommons.unl.edu/usdafsfacpub

Part of the Forest Biology Commons, Forest Management Commons, Other Forestry and Forest Sciences Commons, and the Plant Sciences Commons

Frank, K. L.; Tobin, P. C.; Thistle, H. W. Jr.; and Kalkstein, Laurence S., "Interpretation of gypsy moth frontal advance using meteorology in a conditional algorithm" (2013). USDA Forest Service / UNL Faculty Publications. 250.

https://digitalcommons.unl.edu/usdafsfacpub/250

This Article is brought to you for free and open access by the U.S. Department of Agriculture: Forest Service -National Agroforestry Center at DigitalCommons@University of Nebraska - Lincoln. It has been accepted for inclusion in USDA Forest Service / UNL Faculty Publications by an authorized administrator of DigitalCommons@University of Nebraska - Lincoln. 


\title{
Interpretation of gypsy moth frontal advance using meteorology in a conditional algorithm
}

\author{
K. L. Frank • P. C. Tobin • H. W. Thistle Jr. • \\ Laurence S. Kalkstein
}

Received: 7 September 2011 /Revised: 13 May 2012 / Accepted: 24 June 2012 /Published online: 29 July 2012

(C) ISB 2012

\begin{abstract}
The gypsy moth, Lymantria dispar, is a nonnative species that continues to invade areas in North America. It spreads generally through stratified dispersal where local growth and diffusive spread are coupled with long-distance jumps ahead of the leading edge. Longdistance jumps due to anthropogenic movement of life stages is a well-documented spread mechanism. Another mechanism is the atmospheric transport of early instars and adult males, believed to occur over short distances. However, empirical gypsy moth population data continue to support the possibility of alternative methods of longrange dispersal. Such dispersal events seemed to have occurred in the mid- to late-1990s with spread across Lake Michigan to Wisconsin. Such dispersal would be against the prevailing wind flow for the area and would have crossed a significant physical barrier (Lake Michigan). The climatology
\end{abstract}

Electronic supplementary material The online version of this article (doi:10.1007/s00484-012-0572-4) contains supplementary material, which is available to authorized users.

K. L. Frank $(\bowtie)$

Applied Climatologists, Inc.,

Marco Island, FL 34145, USA

e-mail:klfrank@live.com

P. C. Tobin

USDA Forest Service, Northern Research Station,

Morgantown, WV 26505, USA

H. W. Thistle Jr.

USDA Forest Service, Forest Health Technology Enterprise Team,

Morgantown, WV 26505, USA

L. S. Kalkstein

Department of Geography and Regional Studies,

University of Miami,

Coral Gables, FL 33124, USA of the region shows that vigorous cyclones can result in strong easterly winds in the area at the time when early instars are present. It is hypothesized that these storms would enable individuals to be blown across the Lake and explain the appearance of new population centers observed at several locations on the western shore of Lake Michigan nearly simultaneously. A synoptic climatology model coupled with population dynamics data from the area was parameterized to show an association between transport events and population spread from 1996 to 2007. This work highlights the importance of atmospheric transport events relative to the invasion dynamics of the gypsy moth, and serves as a model for understanding this mechanism of spread in other related biological invasions.

Keywords Atmospheric transport · Biological invasions . Lymantria dispar $\cdot$ Synoptic climatology

\section{Introduction}

Trends in global trade and travel have increased the movement of non-native species to new areas (McCullough et al. 2006; Lockwood et al. 2007). Upon arrival to a novel habitat, some species become established and subsequently spread, imposing ecological and economic costs to the function and composition of native ecosystems (Parker et al. 1999; Mack et al. 2000; Mooney and Cleland 2001). The spread of invasive species often occurs through a process known as stratified dispersal (Hengeveld 1989; Andow et al. 1990; Shigesada and Kawasaki 1997) in which local growth and diffusive spread (e.g., Fisher 1937; Skellam 1951) is coupled with long-distance transport, which can be accomplished through anthropogenic and atmospheric transport 
mechanisms (Isard and Gage 2001; Lockwood et al. 2007). Although both transport mechanisms can be considered as somewhat stochastic, making it challenging to quantify precisely their role in the spread of non-native species, their importance should not be overlooked. For example, some species that are unable to overwinter in northern climates may annually reinvade northern agroecosystems facilitated by atmospheric transport (Isard et al. 2005, 2009). In other invaders, atmospheric transport is thought to facilitate range expansion for non-native species that do not yet occupy the full range of susceptible hosts (Geils et al. 2003; Venette and Ragsdale 2004; Frank et al. 2008). In this paper, advances in synoptic climatology were utilized to address the role of atmospheric transport in the spread of the gypsy moth, Lymantria dispar (L), a non-native invasive species currently expanding its range in North America.

The gypsy moth was introduced to North America in 1869, outside of Boston, Massachusetts (Liebhold et al. 1989). It is a univoltine defoliator that can exploit over 300 deciduous and coniferous host tree species including oak, aspen, willow, apple, and larch (Liebhold et al. 1995). Eggs overwinter and hatch in the spring, and larvae feed for approximately 6-8 weeks, passing though 5-6 instars before pupating. Adults emerge in mid-summer and mate. Since its initial introduction into North America, the gypsy moth has spread and now occupies a range from Nova Scotia to Wisconsin, and Ontario to North Carolina (Tobin et al. 2007). Still, approximately three-quarters of the range of susceptible host tree species has not yet been invaded (Morin et al. 2005), and the gypsy moth is currently invading susceptible habitats to the west and south at highly variable yearly rates from 6 to $18 \mathrm{~km} /$ year (Tobin et al. 2007).

Gypsy moth dispersal is accomplished through neonate ballooning, adult male flight (adult females are incapable of flight), and the anthropogenic movement of life stages (Doane and McManus 1981; Elkinton and Liebhold 1990). The latter mechanism is the primary means through which gypsy moth disperses over very long distances, such as through the movement of household goods from the east to west coast of the United States (Hajek and Tobin 2009).

However, gypsy moth dispersal through atmospheric transport mechanisms could also play a role in its invasion dynamics, particularly along the expanding population front (Tobin and Blackburn 2008). Prior evidence has demonstrated that male moth flight periods can be occassionally bimodal, with one peak of moth flight phenologically corresponding to local climatic conditions and another peak corresponding to climatic conditions elsewhere (Fig. 1, Krause et al. 1994; Tobin et al. 2009a), which suggests an influx of male moths or other life stages from multiple source populations.

Atmospherically assisted male moth dispersal can often be considered as a dead-end in gypsy moth spread dynamics because females are not capable of flight; thus, the presence of males ahead of the leading edge of the population front would not lead to the establishment of new colonies in the absence of females. However, more recent work has suggested that an influx of male moths to areas of low-density populations, which could be subject to an Allee effect (e.g., positive density-dependence, Taylor and Hastings 2005) and thus could be driven to extinction (Whitmire and Tobin 2006), could enable low-density populations to persist (Tobin and Blackburn 2008). In the gypsy moth, the dominant cause of an Allee effect is mate-finding failure, in which males do not locate calling females when male density is low (Sharov et al. 1995; Tcheslavskaia et al. 2002; Contarini et al. 2009; Tobin et al. 2009b). However, supplementing low-density populations with an influx of males that arrive through atmospheric transport mechanisms could negate the demographic effect of mate-finding failure (Tobin and Blackburn 2008); thus, the role of atmospherically assisted male moth dispersal could have particular importance along its expanding population front by facilitating low-density population establishment and persistence. The gypsy moth is furthermore an ideal study system to address the role of atmospheric transport in its invasion dynamics because it continues to spread into new areas along a leading invasion front. There is also a wealth of population monitoring and demographic data available on gypsy moth distribution, life history, the timing of phenological events, and dispersal (Doane and McManus 1981; Elkinton and Liebhold 1990; Tobin and Blackburn 2007), which permits the parameterization of synoptic climatology models and the coupling with population dynamics data to address the role of atmospheric transport in its ongoing invasion of North America.

\section{Materials and methods}

\section{Study system}

Following its initial introduction and successful establishment in Massachusetts, the gypsy moth population expanded incrementally to the north, south, and west. A secondary, spatially discrete, introduction occurred in Michigan, upon which eradication was attempted several times beginning in 1954 (Dreistadt 1983). In 1981, six counties in central Michigan were declared as infested under the gypsy moth quarantine (US Code of Federal Regulations, Title 7, Chapter III, Section 301.45-3, http://law.justia.com/cfr/ title07/7-5.1.1.1.2.html). In 1993, pheromone-baited traps deployed to detect new populations recorded male moths along the Door Peninsula in Wisconsin (Krause et al. 1994). Subsequent survey programs that incorporated a higher trap intensity also recorded male moths in eastern Wisconsin; 
(A)

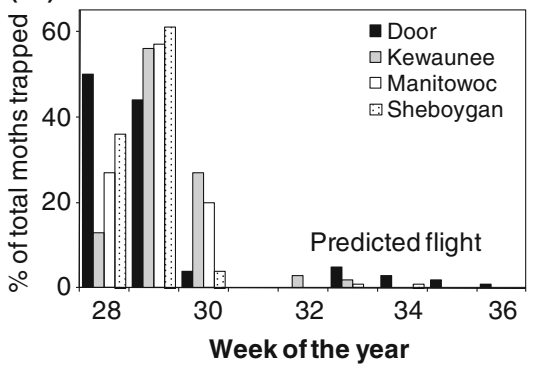

Fig. 1 a Percent of male moths trapped over time in four counties in eastern Wisconsin, 1993, with only a minority of males trapped during the predicted flight period based upon local climatic conditions (modified from Krause et al. 1994). b Frequency distribution of the

however, the spatial pattern suggested that moth captures were not isolated spatially as would be the case with established, reproducing populations, such as those that initialize from the introduction of egg masses (Liebhold and Tobin 2006). Instead, the spatial pattern of the male moth trap catch beginning in 1994 suggested that gypsy moth was introduced at various points in Wisconsin nearly simultaneously (Fig. 2), such as through an atmospheric transport event. The transport of first instars by passive, wind-driven means (i.e., larval ballooning) has been suggested as a primary mechanism of short-range (e.g., tree-to-tree) gypsy moth dispersal (Mason and McManus 1981). For larvae to balloon into Wisconsin from the nearest source populations in Michigan, larvae would have had to be transported $\approx$ $190 \mathrm{~km}$ across Lake Michigan. This would have required a
(B)

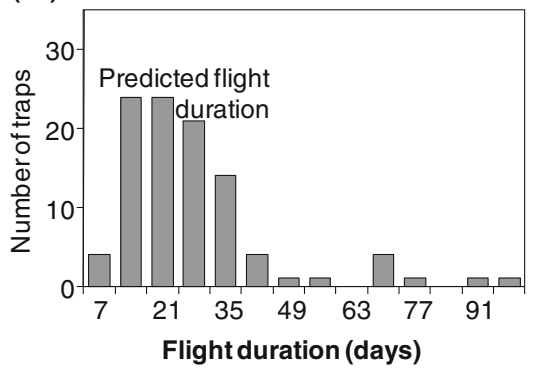

number of traps in Wisconsin, 2004-2008, by the duration of male moth flight, which is predicted to occur over 14-28 days (modified from Tobin et al. 2009a)

strong east-wind event, yet this westward movement is upwind considering the prevailing westerly winds at the latitude of the Michigan-Wisconsin domain. However, a more detailed examination of the wind climatology of the region shows that, although easterly winds are low frequency events at stations far enough from the shore so as not to be dominated by lake effects, the upper Midwest can be subject to vigorous cyclones in mid-spring when early gypsy moth larvae are at their smallest and most likely to be able to balloon longer distances. The counter-clockwise flow around these storms can result in strong easterly winds in the northern quadrant of the cyclones.

The storms show up dramatically on synoptic weather maps (Fig. 3) and generally yield discrete events of prolonged easterly winds across Michigan and Wisconsin,

Fig. 2 Spatial time series of the initial invasion of Wisconsin by the gypsy moth, 1994-2005
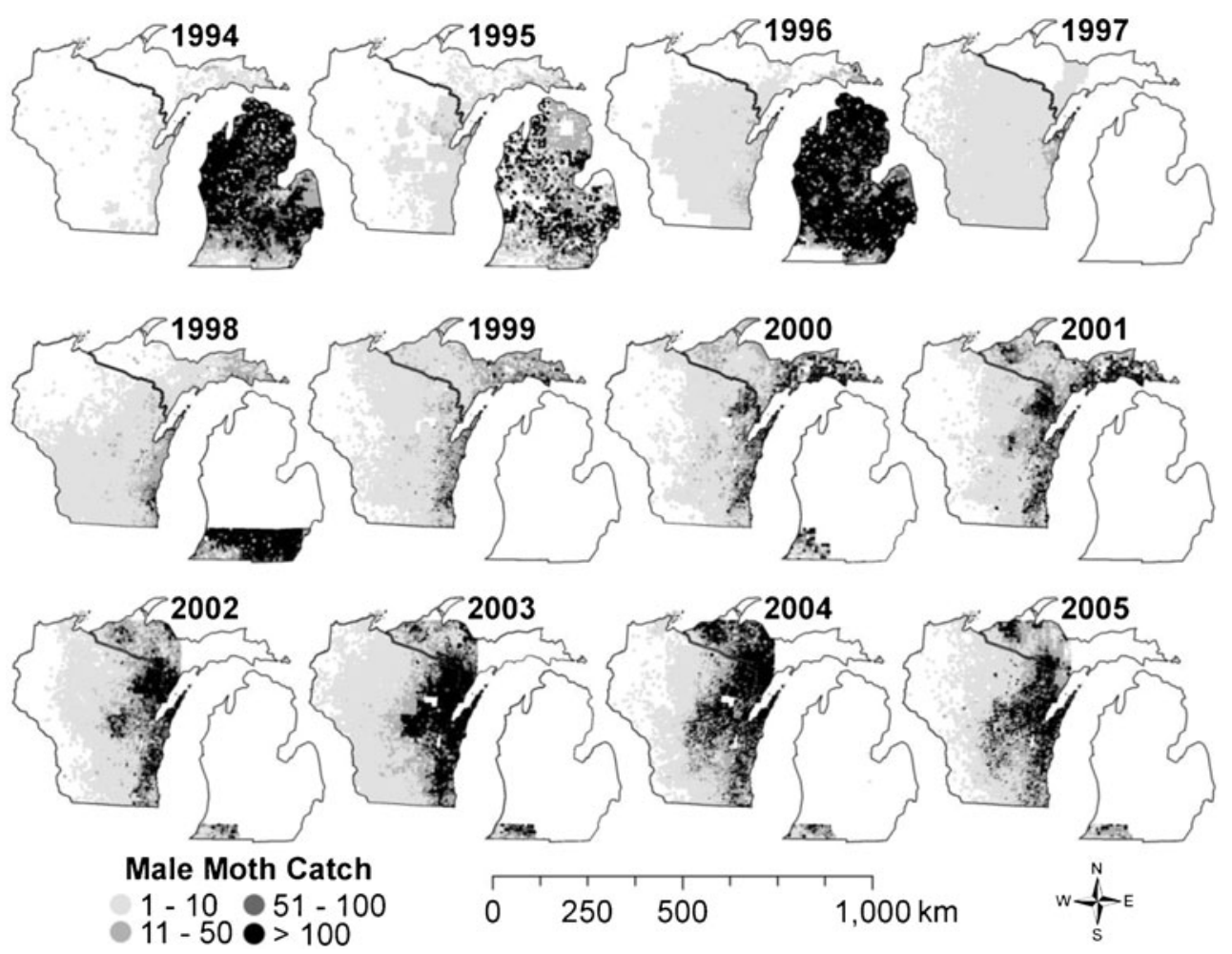


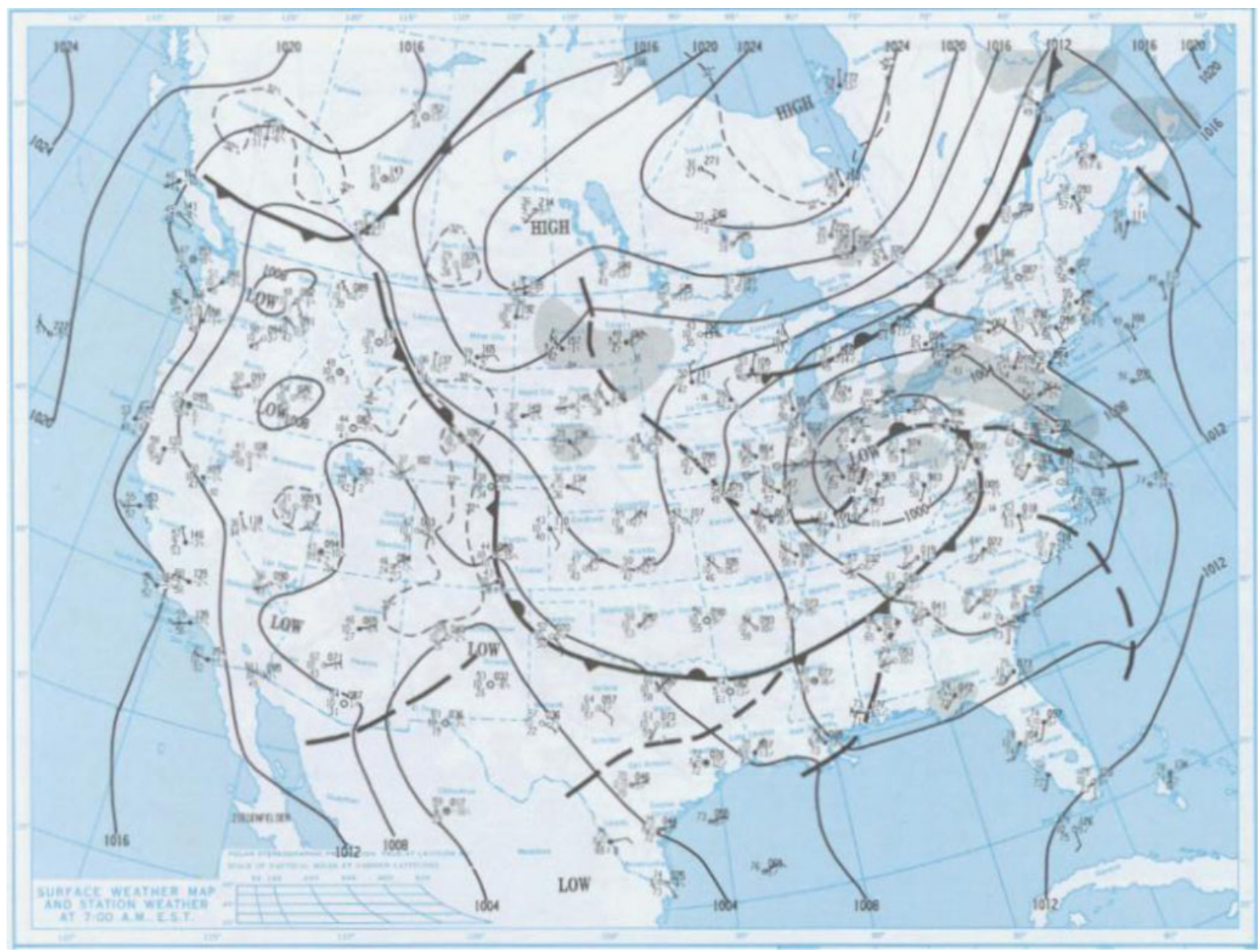

Fig. 3 On 8 May 1998, a cyclone moved from west to east across central Illinois and Indiana, just south of the study area in Michigan and Wisconsin. Winds over the study area were easterly and the area of

depending upon the track of the storms. This synoptic phenomenon occurs predominantly in the spring, coinciding with early gypsy moth instars, although it is observed occasionally at other times of the year. Though these cyclonic passages are often moist, which will limit airborne transport of gypsy moth larvae, they are not always so and the easterly wind region often extends beyond and away from the associated band of precipitation.

The summer months, when adult moths are in flight, are dominated generally by lighter winds across the Great Lakes region as cyclones usually track farther to the north during this season. Easterly winds are most often observed in the summer in association with the clockwise circulation around an anticyclone; however, it is not often that anticyclones are centered far enough to the north that the east wind field in the southern quadrant of the circulation is over central Michigan and Wisconsin.

These factors lead to the consideration of a conditional model to isolate and examine these synoptic events. The precipitation associated with the cyclone did not extend far enough to the north to affect many of the source-target point pairs. The potential transport event that was identified on this day had a weight of 15.57

probabilistic model presented here incorporates meteorological data and population data from potential source populations. The study area included Michigan as a source of gypsy moth populations and Wisconsin as a recipient of gypsy moth life stages in the early years in the study period, and Wisconsin as both a source and recipient in later years when gypsy moth populations were well established in eastern Wisconsin. Meteorological and gypsy moth population data from 1997 to 2007 were considered by this study.

\section{Algorithm development and implementation}

Implementation of the probabilistic model to identify potential long distance dispersal (LDD) events occurs in a series of four steps: identification of potential "east-wind" events, calculation of particle (larvae or adult moth) travel distance, elimination of unsuccessful events and weighting of events based on source population. 


\section{Step 1: Identification of "east-wind" events}

Potential east-wind events were identified as those observations where the wind direction was within $22.5^{\circ}$ of the straight-line direction (a $45^{\circ}$ 'cone of acceptance') from the source population to the location where a new, 'target', population was observed. For the purposes of this study, the weather station nearest the newly observed gypsy moth population served as the target station and the weather station nearest the most proximate 300+-moth-catch area as identified by trap catch data from the previous year served as the source. For example, if the straight-line direction from a weather station at Milwaukee, Wisconsin, where new populations were observed to a $300+$-moth-catch source population area near Grand Rapids, Michigan, is $90^{\circ}$, east-wind events would be those observations with wind directions at Grand Rapids within the $67.5^{\circ}-112.5^{\circ}$ range.

There is a high correlation of wind velocity at proximate stations during the passage of the cyclones that result in "east-wind" events in the study area, as illustrated by Fig. 3, which shows the east-wind region extending approximately $500 \mathrm{~km}$ north-south and $1,000 \mathrm{~km}$ east-west. Thus, because of the spatially correlated wind field in these situations, wind velocity data from a nearby weather station is assumed to be generally representative of the wind velocity at a gypsy moth source even if that source is some distance away from the station at which the wind velocity was observed.

\section{Step 2: Calculation of particle travel distance}

When an "east-wind" event was identified, the distance that a particle would travel each hour was calculated and summed. The hourly distance traveled is based on the wind speed observed at the weather station nearest the source until the total distance traveled is half of the distance between the source and the target. After the halfway point is reached, the hourly distance traveled is calculated based on the wind speed observed at the target. The event ends when the total distance traveled reaches the distance from the source to the target or if one of the elimination criteria described below is met. A new event began for each hour that the wind direction at the source remained within the $\pm 22.5^{\circ}$ range.

\section{Step 3: Elimination of unsuccessful transport events}

Precipitation, wind direction and wind speed were used to eliminate events deemed unsuccessful for transport of particles from the source to the target.

If any rain was observed along the path from the source to the target during the transport event, the event was eliminated. It is assumed that any amount of precipitation will scavenge some larvae or adult moths, thus limiting the success of that transport event. Precipitation was identified by visual interpretation of radar images acquired during each event.

A change in wind direction to a direction outside of the range of $\pm 90^{\circ}$ from the direction used to identify the $\pm 22.5^{\circ}$ cone used to initialize the event during the transport event resulted in the event being identified as unsuccessful. This wind shift would suggest that the wind was no longer blowing in a manner that would allow successful transport to the target in question, rather that the wind would blow any particles to another target area.

For events occurring during the larval stage, if the wind speed (at the source or the target, depending on which is being used to calculate the particle movement at that point in the trajectory) dropped below $2.5 \mathrm{~m} / \mathrm{s}$ for more than 2 consecutive hours, the event was eliminated because it was assumed that the larvae would settle. Larvae have a settling velocity of 0.41 to $1.17 \mathrm{~m} / \mathrm{s}$ depending on the weight of the individual and the length of attached silk (McManus and Mason 1983). Adult moths were assumed to be neutrally buoyant with a negligible forward speed.

\section{Step 4: Weighting of transport events based on source population}

The model was run for the period from $5 \%$ egg hatch to $95 \%$ completion of $2 \mathrm{nd}$ instar (for larval dispersal), and $5 \%$ to $95 \%$ adult emergence. These temporal windows were chosen because 1st instars balloon and adult male moths are capable of flight; these are the most likely stages in which LDD could take place. The phenological periods for gypsy moth were estimated using a phenology model (Gray et al. 1995) interpolated in BioSIM (Régnière and Sharov 1998). A Gaussian population distribution for both of these periods was assumed. Each successful event was matched to the corresponding dates on the population distribution curve and the event was weighted by assigning it a value equal to the height of the population distribution curve at the date when the event began. Thus, events that occurred when fewer individuals were available to experience transport were weighted less than those events that occurred during peak populations. These weights were held unitless because they are based on a Gaussian fit to a phenological prediction rather than the actual population density.

The model identified each hourly observation as successful for transport (i.e., weight $>0$ ) or unsuccessful for transport (i.e., weight $=0$ ) based on the criteria described above. A 48-h running average was calculated of the weights of the hourly observations to identify those events that had a longer duration and that occurred in conjunction with high-population periods at the source. The 2-day window was selected because it was assumed that individuals 
would not be viable under longer transport scenarios. Thus, 48-h periods with total weights of 4 or greater were identified as "most favorable" as they would be representative of $4 \mathrm{~h}$ of favorable wind conditions (a period deemed necessary for a particle to travel from the source to the target) during peak populations.

The weighted events were then compared to the adult male moth trap catch data to determine if transport events correspond with observed changes in the population distribution.

\section{Data}

Four datasets were used to implement the model: (1) wind data from Michigan and (2) wind data from Wisconsin, used to identify successful "east-wind" events; (3) precipitation data for the study area, used to eliminate those events that were interrupted by rainfall; and (4) gypsy moth population data, used to identify periods when individuals would have been present at the source point and available for potential LDD.

Wisconsin wind data were obtained from the Wisconsin State Climatology Office. Wind speed and direction were available only for first-order weather stations in the state on an hourly basis from 1 January 1948 to the present. The first-order stations of interest to this study were Green Bay, Milwaukee and Madison.

Michigan wind data were also available for only firstorder weather stations for the 1948-present time period. However, in Michigan, a more spatially and temporally dense dataset was available from the Enviro-weather Automated Weather Station Network [formerly known as the Michigan Automated Weather Network (MAWN)], whose stations began reporting 1 January 1996. Data from these stations was retrieved on the same hourly temporal resolution as was available in Wisconsin (Michigan State University 2011). Stations were selected as sources based on their proximity to the $300+$ moth catch areas. The sourcetarget pairs for each year in the study period are listed in Appendix 1. As new source stations became available in later years, the closest station to the gypsy moth population of interest was used. As was discussed previously, because of the spatially correlated wind field in the situations in question, the data from a nearby weather station should be generally representative of the source even if that source is some distance away.

Radar imagery from the National Climate Data Center's NEXRAD archive was retrieved for each successful "eastwind" event identified by the model (NCDC 2011, http:// www.ncdc.noaa.gov/nexradinv/). If the hour at which the image was acquired fell within the period when the source wind speed was still being used to calculate distance traveled, any radar return between the source and the halfway point between the source and target eliminated the event. For subsequent hours in the event, any radar return observed between the halfway point and the target eliminated the event.

Male moth trap catch data were available through the gypsy moth Slow-the-Spread program, through which pheromone-baited traps are deployed along the expanding population front (Tobin and Blackburn 2007). Along this expanding front, which currently extends from Minnesota to North Carolina, approximately 120,000 pheromone-baited traps are deployed annually to identify newly founded colonies that arrive ahead of the expanding front. Many of these colonies are targeted for elimination to minimize their contribution to the range expansion of gypsy moth, hence slowing its spread (Sharov and Liebhold 1998). Trap catch data are also used to estimate gypsy moth population boundaries for each year. The spatial displacement of these population boundaries between successive years are used to estimate annual rates of gypsy moth spread (Sharov et al. 1997; Tobin et al. 2007), which are available online (Decision-Support System for the Gypsy Moth Slow-theSpread Program 2011).

\section{Analyses}

The time series of the annual rates of gypsy moth spread (1996-2008) and the sum of the weights of hourly favorable transport periods (larval and adult dispersal combined, 1996-2007) were first tested for temporal autocorrelation using the partial autocorrelation function. Because no significant autocorrelation was detected in either time series, the correlation between the sum of the weights in yeart, and the rate of gypsy moth spread for year $t$ and $t+1$, was tested using the Pearson correlation coefficient-had autocorrelation been detected, Pearson's test would have been invalid (Clifford et al. 1989). Time series data of gypsy moth spread were normalized using standardized deviates, while weights were transformed using $\log _{10}(+1)$, to ensure normality. The sum of the weights was lagged by 1 year because favorable transport events could have an influence on gypsy moth spread in the next year as well as the current year. All statistical analyses were conducted in R (R Development Core Team 2011).

\section{Results and discussion}

The algorithm identified 585 individual hourly transport events over the 1996-2007 study period. Of these, twothirds occurred during the period of early instars, with the month of May having the highest frequency of events; the next most frequent month, July, which would coincide with adult flight, had less than half as many events. Duration of 
events ranged from 4 to $41 \mathrm{~h}$, with a mode of $8 \mathrm{~h}$. The events occurring earlier in the year, during the larval period, tended to be of shorter duration due to higher wind speeds, and were generally more likely to be associated with other transport events than those that occurred during adult flight periods. That is, the overall time required to transport larvae was generally shorter (average $11.8 \mathrm{~h}$ for early instars and $18.8 \mathrm{~h}$ for adults), and these springtime events were more often associated with several consecutive hours of conditions favorable for transport.

As would be expected, more events were identified for target-source pairs that were nearer to one another than for those combinations that would have required a greater transport distance. Source-target pairs that would have required transport toward the south or southwest, as opposed to the west, were generally less likely to achieve successful events during either season.

Weighting of the transport events based on source population showed that some potentially successful transport events occurred during high population periods for both larval and adult flight seasons; however, the sum of the weights of the early instar events was approximately twice that of the adult events. Thus, more of the early instar events occurred during the periods when many individuals were available to be transported from the source than did the events occurring during the adult moth flight seasons.

Grouping the hourly transport events by date of occurrence yielded 66 distinct periods favorable for transport (Appendix 2-electronic). Of these, 14 were individual hourly events occurring on a given day, suggesting that they were not of sufficient duration to result in successful transport. Of the remaining 52 favorable transport periods, 11 were identified as "most favorable" (i.e., had total weights of 4 or greater). Seven and four such periods occurred during the period of early instars and adults, respectively.

Comparison of all of the potential transport events with daily weather maps indicated that 35 of the events were associated with the clockwise circulation around anticyclones (high pressure systems) to the north or northwest of the study area (Fig. 4). However, the average weight of these events is only 1.72. The anticyclonic events are split almost evenly between life stages; 19 are early instar and 16 are adult events. Of the anticyclonic events, 14 follow a frontal passage with a low-pressure center forming generally over Illinois and/or Indiana. The average weight of the anticyclonic events following a frontal passage is 2.53 . Nine of these anticyclonic/frontal events occurred during adult flight and five were during the period of early instars.

Thirty-one of the potential transport events are associated with cyclones (low pressure systems) in or near the study area (Fig. 3). The average weight of all of the cyclonic events is 3.01 and the majority, i.e., 22, of these events are during the period of early instar. Eight of these events are associated with cyclones west of the study area, generally with an anticyclone to the east. The proximity of these storms varies from near the study area to as far west as Kansas and Nebraska. These western cyclonic events have an average weight of 2.64 and all but one occurred during the larval period. Most (22) of the cyclonic events are cyclones passing over or just south of the study area. These events have an average weight of 3.26 and more than two-thirds of them occur during the early instar period. One adult event with a weight of 0.59 is associated with a cyclone to the northeast of the study area.

There were seven events during the period of early instars with weights greater than 4 , which were identified as "most favorable" for transport; six involved cyclone passages just to the south of the study area. The other event was a cyclone to the west of the study area accompanied by an anticyclone to the north and east. Although this event was persistent in that $52 \mathrm{~h}$ over a 4-day period were favorable for transport, the overall event weight was less than other, less persistent, events involving cyclone passages. Of the four adult events with weights over 4, all were anticyclonic events with the anticyclones to the north/northwest of the study area. Wind speeds in these situations were much lower than during cyclonic passages.

A graphical comparison between yearly gypsy moth spread rates in northern, central, southern Wisconsin as well as across the state as a whole with the corresponding weights of the "most favorable" larval and adult transport events is presented in Fig. 5. The limited weather data available for the initial years of the study period restricted results from the model; however, as the more dense observing network became available in 2000, with additional stations added each subsequent year, results from the later years of the study are more robust. A general relationship across all regions of Wisconsin is that higher annual gypsy moth spread rates tend to be associated with the years with the most favorable transport events as identified by the model. When assessing annual, state-wide spread rates with the sum of the larval and adult "most favorable" weights, a significant correlation was observed when using the current year spread rates $(r=0.58, P=0.05$; Fig. $6 \mathrm{a})$. When associating the sum of the weights with spread rates in the following year, there was a positive trend that was not significant ( $r=0.44, P=0.16$; Fig. $6 \mathrm{~b}$ ), suggesting that transport events have a more immediate impact on gypsy moth spread even though higher spread rates in the following year are often associated with higher model weights.

A year-by-year comparison of the movement of the gypsy moth front in the three regions of Wisconsin and the model results suggest that greatest advances of the population front 


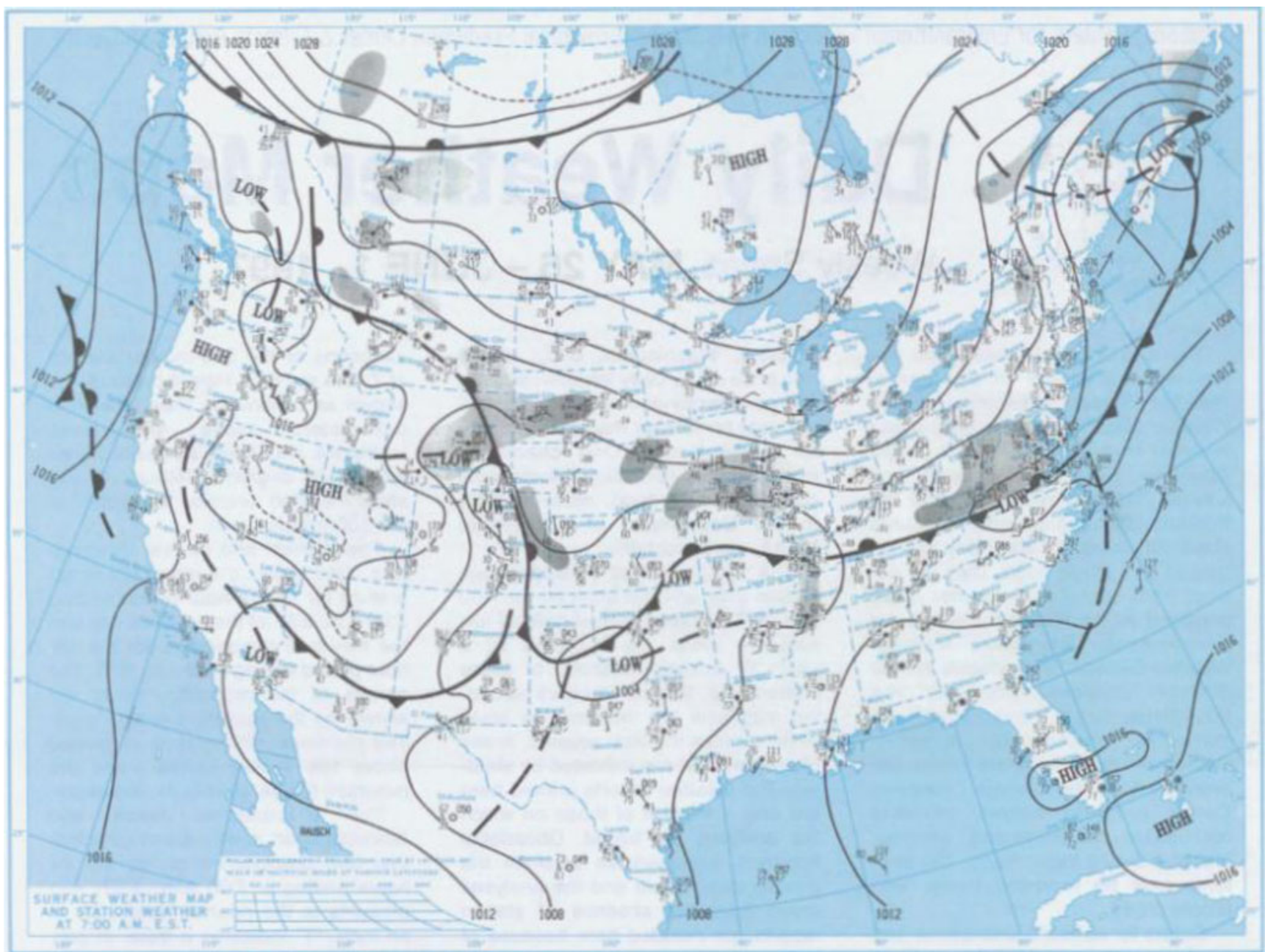

Fig. 4 On 26 May 1997, there was an anticyclone centered north of the study area in Michigan and Wisconsin and a cyclone forming to the south of the study area. Winds over the study area were easterly.
The potential transport event that was identified on this day had a weight of 15.54
Fig. 5 Annual gypsy moth spread rates (grey bars) in a northern, $\mathbf{b}$ central, $\mathbf{c}$ southern, and $\mathbf{d}$ the mean rate state-wide relative to the corresponding model weights of favorable transport events for larval (dotted line), adult (dashed line), both life stages combined (solid line), 1996-2007. Note the correspondence between high rates of spread and model weights for 1997 and 2007, and low rates of spread and model weights for 2004-2006
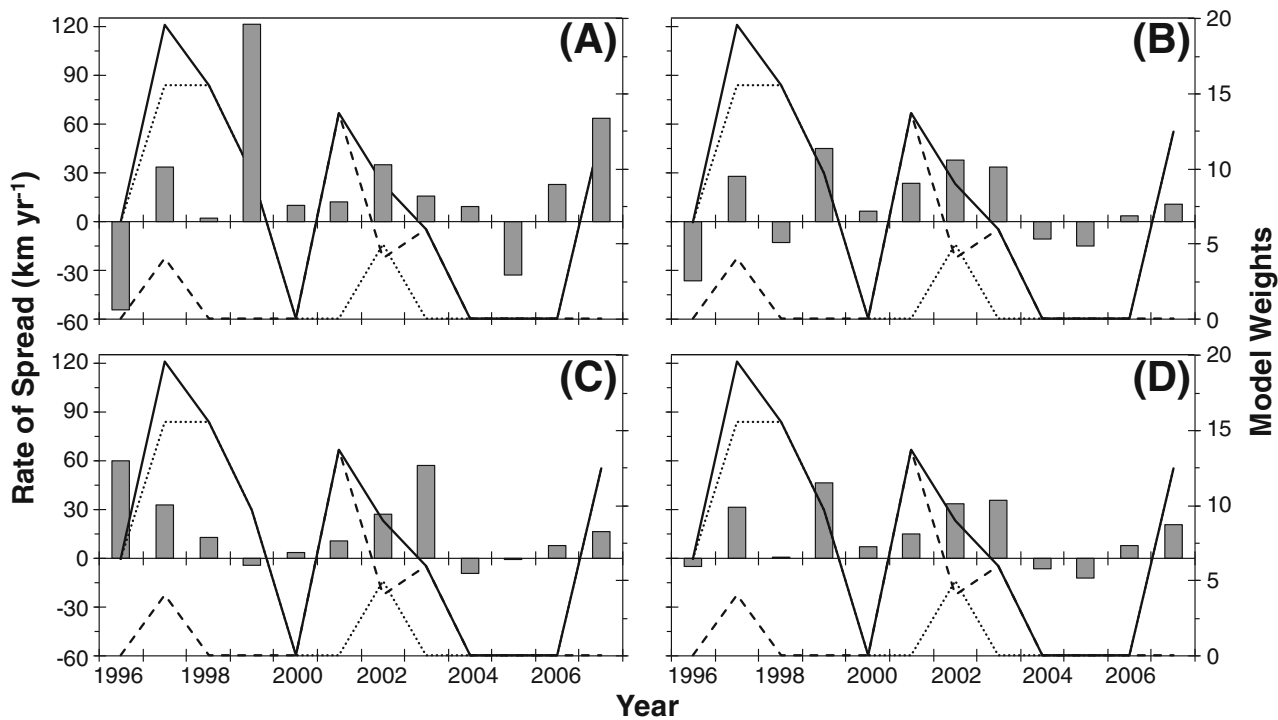
Fig. 6 Relationship between the sum of the weights representing "most favorable" larval and adult transport events and the annual rate of gypsy moth spread in Wisconsin in a the current year and $\mathbf{b}$ the following year. The line represents the general trend. Note that in years with higher weights that there tends to be a higher rate of gypsy moth spread

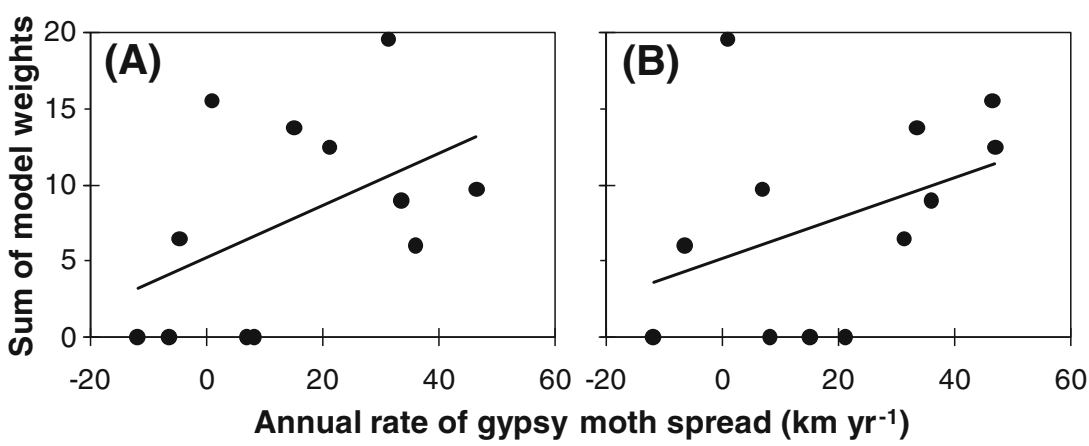

to the north of the study area, but were also, on occasion, the result of a stronger east-wind field created by the passage of a storm to the south. While the low frequency of these cyclone-to-the-south events during adult flight periods suggests that they are likely not the primary mechanism for movement of individuals, it does support the observations of bimodal peaks in the adult moth-catch data (i.e., Krause et al. 1994; Tobin et al. 2009a).

Windborne transport of gypsy moth is known to occur over short distances and this study supports the assertion that larger geographic barriers such as Lake Michigan may be overcome in specific atmospheric scenarios. Moreover, since 2007, the gypsy moth front in the Great Lakes region has continued to expand to the north and west, and gypsy moth populations have progressed into northeastern Minnesota. Examination of this expansion, which would also occur over a significant physical barrier (i.e., Lake Superior) and also against the prevailing wind direction, provides an opportunity to refine and further validate the model developed in this paper.

As new species continue to arrive and establish in new areas, it is important to quantify the roles of different modes of transport to develop and optimize the management of invasion pathways. Although trade is a dominate invasion pathway by which new species are transported among and within continents and countries (Levine and D'Antonio 2003; Hulme et al. 2008), the importance of other mechanisms, such as atmospheric transport events (Isard et al. 2005; Frank et al. 2008), should not be overlooked. Because many biological invaders are subject to Allee effects at lowdensities (Taylor and Hastings 2005), such as when populations are too sparse for individuals to locate mates successfully, the introduction of additional individuals through atmospheric transport mechanisms could augment existing population densities, thereby facilitating population persistence (Tobin and Blackburn 2008). A general application of this type of species dispersal information is in the management decisions made to monitor and combat invasive species. Determination of transport distances and identification of transport events allows informed design of monitoring areas and anticipation of growing seasons likely to show high dispersion. Such information allows for the judicious targeting of finite management resources.

\footnotetext{
${ }^{1}$ The moth front moved to the northwest in 1999, a direction that was not included in the model's screen for wind direction due to the limited number of source-target pairs with meteorological data available in that year. The model did not identify any events suggesting the observed spread that year, but user-interpretation of the daily weather maps and moth population data suggests that it would likely have done so had the event occurred later in the study period.
} 


\section{Appendix 1}

Table 1 Source-target pairs examined in this study that were selected based on moth population and available meteorological data in each year Source Point Target Point $\quad$ Distance (m) Direction $\quad$ Michigan weather $\quad 5 \%$ hatch $\quad 5 \% 2$ nd instar $\quad 5 \%$ adult $\quad 95 \%$ adult station used

\begin{tabular}{|c|c|c|c|c|c|c|c|c|}
\hline \multicolumn{9}{|l|}{1996} \\
\hline West Olive & Green Bay & 233,031 & 140 & East Lansing & 11 May & 14 June & 2 August & 21 August \\
\hline West Olive & Milwaukee & 144,196 & 95 & East Lansing & 11 May & 14 June & 2 August & 21 August \\
\hline West Olive & Madison & 265,861 & 93 & East Lansing & 11 May & 14 June & 2 August & 21 August \\
\hline Arlene & Green Bay & 505,600 & 95 & East Lansing & 20 May & 14 June & 12 August & 21 August \\
\hline Arlene & Milwaukee & 264,200 & 52 & East Lansing & 20 May & 14 June & 12 August & 21 August \\
\hline Arlene & Madison & 353,400 & 66 & East Lansing & 20 May & 14 June & 12 August & 21 August \\
\hline \multicolumn{9}{|l|}{1997} \\
\hline Benzonia & Green Bay & 424,600 & 94 & Hart & 16 May & 24 June & 7 August & 4 September \\
\hline Benzonia & Milwaukee & 228,800 & 38 & Hart & 16 May & 24 June & 7 August & 4 September \\
\hline Benzonia & Madison & 302,200 & 58 & Hart & 16 May & 24 June & 7 August & 4 September \\
\hline Hart & Green Bay & 426,400 & 107 & Hart & 6 May & 14 June & 7 August & 17 August \\
\hline Hart & Milwaukee & 152,200 & 55 & Hart & 6 May & 14 June & 7 August & 17 August \\
\hline Hart & Madison & 249,200 & 74 & Hart & 6 May & 14 June & 7 August & 17 August \\
\hline Hudsonville & Green Bay & 500,700 & 116 & East Lansing & 6 May & 14 June & 27 July & 17 August \\
\hline Hudsonville & Milwaukee & 164,100 & 92 & East Lansing & 6 May & 14 June & 27 July & 17 August \\
\hline Hudsonville & Madison & 281,400 & 95 & East Lansing & 6 May & 14 June & 27 July & 17 August \\
\hline \multicolumn{9}{|l|}{$1998 \mathrm{e}$} \\
\hline Benzonia & Green Bay & 424,600 & 94 & Hart & 24 April & 26 May & 20 July & 3 August \\
\hline Benzonia & Milwaukee & 228,800 & 38 & Hart & 24 April & 26 May & 20 July & 3 August \\
\hline Benzonia & Madison & 302,200 & 58 & Hart & 24 April & 26 May & 20 July & 3 August \\
\hline Hart & Green Bay & 426,400 & 107 & Hart & 24 April & 19 May & 12 July & 3 August \\
\hline Hart & Milwaukee & 152,200 & 55 & Hart & 24 April & 19 May & 12 July & 3 August \\
\hline Hart & Madison & 249,200 & 74 & Hart & 24 April & 19 May & 12 July & 3 August \\
\hline Hudsonville & Green Bay & 500,700 & 116 & East Lansing & 16 April & 19 May & 12 July & 24 July \\
\hline Hudsonville & Milwaukee & 164,100 & 92 & East Lansing & 16 April & 19 May & 12 July & 24 July \\
\hline Hudsonville & Madison & 281,400 & 95 & East Lansing & 16 April & 19 May & 12 July & 24 July \\
\hline \multicolumn{9}{|l|}{1999} \\
\hline Benzonia & Green Bay & 424,600 & 94 & Hart & 27 April & 30 May & 18 July & 14 August \\
\hline Benzonia & Milwaukee & 228,800 & 38 & Hart & 27 April & 30 May & 18 July & 14 August \\
\hline Benzonia & Madison & 302,200 & 58 & Hart & 27 April & 30 May & 18 July & 14 August \\
\hline Hart & Green Bay & 426,400 & 107 & Hart & 27 April & 30 May & 18 July & 29 July \\
\hline Hart & Milwaukee & 152,200 & 55 & Hart & 27 April & 30 May & 18 July & 29 July \\
\hline Hart & Madison & 249,200 & 74 & Hart & 27 April & 30 May & 18 July & 29 July \\
\hline Hudsonville & Green Bay & 500,700 & 116 & East Lansing & 27 April & 23 May & 8 July & 29 July \\
\hline Hudsonville & Milwaukee & 164,100 & 92 & East Lansing & 27 April & 23 May & 8 July & 29 July \\
\hline Hudsonville & Madison & 281,400 & 95 & East Lansing & 27 April & 23 May & 8 July & 29 July \\
\hline \multicolumn{9}{|l|}{2000} \\
\hline Benzonia & Green Bay & 424,600 & 94 & Traverse City & 29 April & 4 June & 4 August & 13 August \\
\hline Benzonia & Milwaukee & 228,800 & 38 & Traverse City & 29 April & 4 June & 4 August & 13 August \\
\hline Benzonia & Madison & 302,200 & 58 & Traverse City & 29 April & 4 June & 4 August & 13 August \\
\hline Hart & Green Bay & 426,400 & 107 & Hart & 21 April & 27 May & 26 July & 13 August \\
\hline Hart & Milwaukee & 152,200 & 55 & Hart & 21 April & 27 May & 26 July & 13 August \\
\hline Hart & Madison & 249,200 & 74 & Hart & 21 April & 27 May & 26 July & 13 August \\
\hline Hudsonville & Green Bay & 500,700 & 116 & East Lansing & 13 April & 19 May & 17 July & 29 July \\
\hline Hudsonville & Milwaukee & 164,100 & 92 & East Lansing & 13 April & 19 May & 17 July & 29 July \\
\hline
\end{tabular}


Table 1 (continued)

\begin{tabular}{|c|c|c|c|c|c|c|c|c|}
\hline Source Point & Target Point & Distance (m) & Direction & $\begin{array}{l}\text { Michigan weather } \\
\text { station used }\end{array}$ & $5 \%$ hatch & $5 \%$ 2nd instar & $5 \%$ adult & $95 \%$ adult \\
\hline $\begin{array}{l}\text { Hudsonville } \\
2001\end{array}$ & Madison & 281,400 & 95 & East Lansing & 13 April & 19 May & 17 July & 29 July \\
\hline Benzonia & Green Bay & 424,600 & 94 & Traverse City & 29 April & 8 June & 26 July & 3 August \\
\hline Benzonia & Milwaukee & 228,800 & 38 & Traverse City & 29 April & 8 June & 26 July & 3 August \\
\hline Benzonia & Madison & 302,200 & 58 & Traverse City & 29 April & 8 June & 26 July & 3 August \\
\hline Hart & Green Bay & 426,400 & 107 & Hart & 29 April & 31 May & 26 July & 3 August \\
\hline Hart & Milwaukee & 152,200 & 55 & Hart & 29 April & 31 May & 26 July & 3 August \\
\hline Hart & Madison & 249,200 & 74 & Hart & 29 April & 31 May & 26 July & 3 August \\
\hline Hudsonville & Green Bay & 500,700 & 116 & West Olive & 29 April & 23 May & 17 July & 3 August \\
\hline Hudsonville & Milwaukee & 164,100 & 92 & West Olive & 29 April & 23 May & 17 July & 3 August \\
\hline Hudsonville & Madison & 281,400 & 95 & West Olive & 29 April & 23 May & 17 July & 3 August \\
\hline Escanaba & Green Bay & 155,623 & 29 & Traverse City & 8 May & 14 June & 14 August & 20 August \\
\hline Escanaba & Milwaukee & 308,027 & 12 & Traverse City & 8 May & 14 June & 14 August & 20 August \\
\hline Escanaba & Madison & 350,352 & 32 & Traverse City & 8 May & 14 June & 14 August & 20 August \\
\hline Green Bay & Milwaukee & 357,500 & 306 & Green Bay & 29 April & 8 June & 26 July & 17 August \\
\hline Green Bay & Madison & 258,800 & 138 & Green Bay & 29 April & 8 June & 26 July & 17 August \\
\hline Milwaukee & Green Bay & 357,500 & 126 & Milwaukee & 29 April & 31 May & 17 July & 3 August \\
\hline $\begin{array}{l}\text { Milwaukee } \\
2002\end{array}$ & Madison & 117,900 & 80 & Milwaukee & 29 April & 31 May & 17 July & 3 August \\
\hline Benzonia & Green Bay & 424,600 & 94 & Benzonia & 8 May & 15 June & 28 July & 8 August \\
\hline Benzonia & Milwaukee & 228,800 & 38 & Benzonia & 8 May & 15 June & 28 July & 8 August \\
\hline Benzonia & Madison & 302,200 & 58 & Benzonia & 8 May & 15 June & 28 July & 8 August \\
\hline Hart & Green Bay & 426,400 & 107 & Hart & 8 May & 7 June & 28 July & 8 August \\
\hline Hart & Milwaukee & 152,200 & 55 & Hart & 8 May & 7 June & 28 July & 8 August \\
\hline Hart & Madison & 249,200 & 74 & Hart & 8 May & 7 June & 28 July & 8 August \\
\hline Hudsonville & Green Bay & 500,700 & 116 & West Olive & 28 April & 30 May & 19 July & 24 July \\
\hline Hudsonville & Milwaukee & 164,100 & 92 & West Olive & 28 April & 30 May & 19 July & 24 July \\
\hline Hudsonville & Madison & 281,400 & 95 & West Olive & 28 April & 30 May & 19 July & 24 July \\
\hline Escanaba & Green Bay & 155,622 & 29 & Traverse City & 26 May & 24 June & 9 August & 26 August \\
\hline Escanaba & Milwaukee & 308,026 & 12 & Traverse City & 26 May & 24 June & 9 August & 26 August \\
\hline Escanaba & Madison & 350,352 & 32 & Traverse City & 26 May & 24 June & 9 August & 26 August \\
\hline Stephenson & Green Bay & 104,767 & 18 & Traverse City & 25 May & 21 June & 6 August & 23 August \\
\hline Stephenson & Milwaukee & 265,057 & 5 & Traverse City & 25 May & 21 June & 6 August & 23 August \\
\hline Stephenson & Madison & 297,083 & 29 & Traverse City & 25 May & 21 June & 6 August & 23 August \\
\hline Green Bay & Milwaukee & 357,500 & 306 & Green Bay & 8 May & 15 June & 28 July & 8 August \\
\hline Green Bay & Madison & 258,800 & 138 & Green Bay & 8 May & 15 June & 28 July & 8 August \\
\hline Milwaukee & Green Bay & 357,500 & 126 & Milwaukee & 28 April & 7 June & 19 July & 24 July \\
\hline $\begin{array}{l}\text { Milwaukee } \\
2003\end{array}$ & Madison & 117,900 & 80 & Milwaukee & 28 April & 7 June & 19 July & 24 July \\
\hline Benzonia & Green Bay & 424,600 & 94 & Benzonia & 5 May & 15 June & 5 August & 20 August \\
\hline Benzonia & Milwaukee & 228,800 & 38 & Benzonia & 5 May & 15 June & 5 August & 20 August \\
\hline Benzonia & Madison & 302,200 & 58 & Benzonia & 5 May & 15 June & 5 August & 20 August \\
\hline Hart & Green Bay & 426,400 & 107 & Hart & 28 April & 7 June & 5 August & 20 August \\
\hline Hart & Milwaukee & 152,200 & 55 & Hart & 28 April & 7 June & 5 August & 20 August \\
\hline Hart & Madison & 249,200 & 74 & Hart & 28 April & 7 June & 5 August & 20 August \\
\hline Hudsonville & Green Bay & 500,700 & 116 & West Olive & 28 April & 31 May & 24 July & 4 August \\
\hline Hudsonville & Milwaukee & 164,100 & 92 & West Olive & 28 April & 31 May & 24 July & 4 August \\
\hline Hudsonville & Madison & 281,400 & 95 & West Olive & 28 April & 31 May & 24 July & 4 August \\
\hline
\end{tabular}


Table 1 (continued)

\begin{tabular}{|c|c|c|c|c|c|c|c|c|}
\hline Source Point & Target Point & Distance (m) & Direction & $\begin{array}{l}\text { Michigan weather } \\
\text { station used }\end{array}$ & $5 \%$ hatch & $5 \% 2$ nd instar & $5 \%$ adult & $95 \%$ adult \\
\hline Escanaba & Green Bay & 155,622 & 29 & Traverse City & 17 May & 19 June & 11 August & 27 August \\
\hline Escanaba & Milwaukee & 308,026 & 12 & Traverse City & 17 May & 19 June & 11 August & 27 August \\
\hline Escanaba & Madison & 350,352 & 32 & Traverse City & 17 May & 19 June & 11 August & 27 August \\
\hline Stephenson & Green Bay & 104,767 & 18 & Traverse City & 14 May & 16 June & 8 August & 23 August \\
\hline Stephenson & Milwaukee & 265,057 & 5 & Traverse City & 14 May & 16 June & 8 August & 23 August \\
\hline Stephenson & Madison & 297,083 & 29 & Traverse City & 14 May & 16 June & 8 August & 23 August \\
\hline Green Bay & Milwaukee & 357,500 & 306 & Green Bay & 5 May & 15 June & 5 August & 20 August \\
\hline Green Bay & Madison & 258,800 & 138 & Green Bay & 5 May & 15 June & 5 August & 20 August \\
\hline Milwaukee & Green Bay & 357,500 & 126 & Milwaukee & 28 April & 7 June & 24 July & 4 August \\
\hline $\begin{array}{l}\text { Milwaukee } \\
2004\end{array}$ & Madison & 117,900 & 80 & Milwaukee & 28 April & 7 June & 24 July & 4 August \\
\hline Benzonia & Green Bay & 424,600 & 94 & Benzonia & 7 May & 12 June & 6 August & 3 September \\
\hline Benzonia & Milwaukee & 228,800 & 38 & Benzonia & 7 May & 12 June & 6 August & 3 September \\
\hline Benzonia & Madison & 302,200 & 58 & Benzonia & 7 May & 12 June & 6 August & 3 September \\
\hline Hart & Green Bay & 426,400 & 107 & Hart & 28 April & 4 June & 26 July & 15 August \\
\hline Hart & Milwaukee & 152,200 & 55 & Hart & 28 April & 4 June & 26 July & 15 August \\
\hline Hart & Madison & 249,200 & 74 & Hart & 28 April & 4 June & 26 July & 15 August \\
\hline Hudsonville & Green Bay & 500,700 & 116 & West Olive & 20 April & 28 May & 16 July & 27 July \\
\hline Hudsonville & Milwaukee & 164,100 & 92 & West Olive & 20 April & 28 May & 16 July & 27 July \\
\hline Hudsonville & Madison & 281,400 & 95 & West Olive & 20 April & 28 May & 16 July & 27 July \\
\hline Escanaba & Green Bay & 155,622 & 29 & Escanaba & 20 May & 22 June & 28 August & 16 September \\
\hline Escanaba & Milwaukee & 308,026 & 12 & Escanaba & 20 May & 22 June & 28 August & 16 September \\
\hline Escanaba & Madison & 350,352 & 32 & Escanaba & 20 May & 22 June & 28 August & 16 September \\
\hline Stephenson & Green Bay & 104,767 & 18 & Stephenson & 15 May & 17 June & 19 August & 9 September \\
\hline Stephenson & Milwaukee & 265,057 & 5 & Stephenson & 15 May & 17 June & 19 August & 9 September \\
\hline Stephenson & Madison & 297,083 & 29 & Stephenson & 15 May & 17 June & 19 August & 9 September \\
\hline Green Bay & Milwaukee & 357,500 & 306 & Green Bay & 7 May & 12 June & 6 August & 3 September \\
\hline Green Bay & Madison & 258,800 & 138 & Green Bay & 7 May & 12 June & 6 August & 3 September \\
\hline Milwaukee & Green Bay & 357,500 & 126 & Milwaukee & 28 April & 28 May & 16 July & 27 July \\
\hline $\begin{array}{l}\text { Milwaukee } \\
2005\end{array}$ & Madison & 117,900 & 80 & Milwaukee & 28 April & 28 May & 16 July & 27 July \\
\hline Benzonia & Green Bay & 424,600 & 94 & Benzonia & 26 April & 7 June & 19 July & 3 August \\
\hline Benzonia & Milwaukee & 228,800 & 38 & Benzonia & 26 April & 7 June & 19 July & 3 August \\
\hline Benzonia & Madison & 302,200 & 58 & Benzonia & 26 April & 7 June & 19 July & 3 August \\
\hline Hart & Green Bay & 426,400 & 107 & Hart & 17 April & 31 May & 19 July & 3 August \\
\hline Hart & Milwaukee & 152,200 & 55 & Hart & 17 April & 31 May & 19 July & 3 August \\
\hline Hart & Madison & 249,200 & 74 & Hart & 17 April & 31 May & 19 July & 3 August \\
\hline Hudsonville & Green Bay & 500,700 & 116 & West Olive & 17 April & 31 May & 10 July & 3 August \\
\hline Hudsonville & Milwaukee & 164,100 & 92 & West Olive & 17 April & 31 May & 10 July & 3 August \\
\hline Hudsonville & Madison & 281,400 & 95 & West Olive & 17 April & 31 May & 10 July & 3 August \\
\hline Escanaba & Green Bay & 155,622 & 29 & Escanaba & 12 May & 13 June & 2 August & 18 August \\
\hline Escanaba & Milwaukee & 308,026 & 12 & Escanaba & 12 May & 13 June & 2 August & 18 August \\
\hline Escanaba & Madison & 350,352 & 32 & Escanaba & 12 May & 13 June & 2 August & 18 August \\
\hline Stephenson & Green Bay & 104,767 & 18 & Stephenson & 11 May & 10 June & 28 July & 12 August \\
\hline Stephenson & Milwaukee & 265,057 & 5 & Stephenson & 11 May & 10 June & 28 July & 12 August \\
\hline Stephenson & Madison & 297,083 & 29 & Stephenson & 11 May & 10 June & 28 July & 12 August \\
\hline Green Bay & Milwaukee & 357,500 & 306 & Green Bay & 4 May & 7 June & 19 July & 3 August \\
\hline Green Bay & Madison & 258,800 & 138 & Green Bay & 4 May & 7 June & 19 July & 3 August \\
\hline
\end{tabular}


Table 1 (continued)

\begin{tabular}{|c|c|c|c|c|c|c|c|c|}
\hline Source Point & Target Point & Distance (m) & Direction & $\begin{array}{l}\text { Michigan weather } \\
\text { station used }\end{array}$ & $5 \%$ hatch & $5 \% 2$ nd instar & $5 \%$ adult & $95 \%$ adult \\
\hline Milwaukee & Green Bay & 357,500 & 126 & Milwaukee & 17 April & 31 May & 10 July & 21 July \\
\hline $\begin{array}{l}\text { Milwaukee } \\
2006\end{array}$ & Madison & 117,900 & 80 & Milwaukee & 17 April & 31 May & 10 July & 21 July \\
\hline Benzonia & Green Bay & 424,600 & 94 & Benzonia & 2 May & 2 June & 26 July & 5 August \\
\hline Benzonia & Milwaukee & 228,800 & 38 & Benzonia & 2 May & 2 June & 26 July & 5 August \\
\hline Benzonia & Madison & 302,200 & 58 & Benzonia & 2 May & 2 June & 26 July & 5 August \\
\hline Hart & Green Bay & 426,400 & 107 & Hart & 24 April & 2 June & 17 July & 5 August \\
\hline Hart & Milwaukee & 152,200 & 55 & Hart & 24 April & 2 June & 17 July & 5 August \\
\hline Hart & Madison & 249,200 & 74 & Hart & 24 April & 2 June & 17 July & 5 August \\
\hline Hudsonville & Green Bay & 500,700 & 116 & West Olive & 24 April & 25 May & 17 July & 5 August \\
\hline Hudsonville & Milwaukee & 164,100 & 92 & West Olive & 24 April & 25 May & 17 July & 5 August \\
\hline Hudsonville & Madison & 281,400 & 95 & West Olive & 24 April & 25 May & 17 July & 5 August \\
\hline Escanaba & Green Bay & 155,622 & 29 & Escanaba & 5 May & 10 June & 31 July & 16 August \\
\hline Escanaba & Milwaukee & 308,026 & 12 & Escanaba & 5 May & 10 June & 31 July & 16 August \\
\hline Escanaba & Madison & 350,352 & 32 & Escanaba & 5 May & 10 June & 31 July & 16 August \\
\hline Stephenson & Green Bay & 104,767 & 18 & Stephenson & 4 May & 6 June & 28 July & 13 August \\
\hline Stephenson & Milwaukee & 265,057 & 5 & Stephenson & 4 May & 6 June & 28 July & 13 August \\
\hline Stephenson & Madison & 297,083 & 29 & Stephenson & 4 May & 6 June & 28 July & 13 August \\
\hline Green Bay & Milwaukee & 357,500 & 306 & Green Bay & 2 May & 2 June & 26 July & 5 August \\
\hline Green Bay & Madison & 258,800 & 138 & Green Bay & 2 May & 2 June & 26 July & 5 August \\
\hline Milwaukee & Green Bay & 357,500 & 126 & Milwaukee & 24 April & 2 June & 17 July & 5 August \\
\hline $\begin{array}{l}\text { Milwaukee } \\
2007\end{array}$ & Madison & 117,900 & 80 & Milwaukee & 24 April & 2 June & 17 July & 5 August \\
\hline Benzonia & Green Bay & 424,600 & 94 & Benzonia & 5 May & 31 May & 25 July & 8 August \\
\hline Benzonia & Milwaukee & 228,800 & 38 & Benzonia & 5 May & 31 May & 25 July & 8 August \\
\hline Benzonia & Madison & 302,200 & 58 & Benzonia & 5 May & 31 May & 25 July & 8 August \\
\hline Hart & Green Bay & 426,400 & 107 & Hart & 28 April & 23 May & 17 July & 29 July \\
\hline Hart & Milwaukee & 152,200 & 55 & Hart & 28 April & 23 May & 17 July & 29 July \\
\hline Hart & Madison & 249,200 & 74 & Hart & 28 April & 23 May & 17 July & 29 July \\
\hline Hudsonville & Green Bay & 500,700 & 116 & West Olive & 20 April & 23 May & 8 July & 19 July \\
\hline Hudsonville & Milwaukee & 164,100 & 92 & West Olive & 20 April & 23 May & 8 July & 19 July \\
\hline Hudsonville & Madison & 281,400 & 95 & West Olive & 20 April & 23 May & 8 July & 19 July \\
\hline Escanaba & Green Bay & 155,623 & 29 & Escanaba & 6 May & 9 June & 2 August & 19 August \\
\hline Escanaba & Milwaukee & 308,027 & 12 & Escanaba & 6 May & 9 June & 2 August & 19 August \\
\hline Escanaba & Madison & 350,352 & 32 & Escanaba & 6 May & 9 June & 2 August & 19 August \\
\hline Stephenson & Green Bay & 104,768 & 18 & Stephenson & 5 May & 5 June & 28 July & 12 August \\
\hline Stephenson & Milwaukee & 265,057 & 5 & Stephenson & 5 May & 5 June & 28 July & 12 August \\
\hline Stephenson & Madison & 297,083 & 29 & Stephenson & 5 May & 5 June & 28 July & 12 August \\
\hline Green Bay & Milwaukee & 357,500 & 306 & Green Bay & 5 May & 31 May & 25 July & 8 August \\
\hline Green Bay & Madison & 258,800 & 138 & Green Bay & 5 May & 31 May & 25 July & 8 August \\
\hline Milwaukee & Green Bay & 357,500 & 126 & Milwaukee & 28 April & 23 May & 8 July & 29 July \\
\hline Milwaukee & Madison & 117,900 & 80 & Milwaukee & 28 April & 23 May & 8 July & 29 July \\
\hline
\end{tabular}




\section{References}

Andow DA, Kareiva PM, Levin SA, Okubo A (1990) Spread of invading organisms. Landscape Ecol 4:177-188

Clifford P, Richardson S, Hémon D (1989) Assessing the significance of the correlation between two spatial processes. Biometrics 45:123-134

Contarini M, Onufrieva KS, Thorpe KW, Raffa KF, Tobin PC (2009) Mate-finding failure as an important cause of Allee effects along the leading edge of an invading insect population. Entomol Exp Appl 133:307-314

Decision-Support System for the Gypsy Moth Slow the Spread Program (2011) http://da.ento.vt.edu/. Accessed 26 March 2011

Doane CC, McManus ME (eds) (1981) The gypsy moth: research toward integrated pest management. US Dept Agric For Serv Gen Tech Bull 1584, Washington, DC

Dreistadt SH (1983) An assessment of gypsy moth eradication attempts in Michigan (Lepidoptera: Lymantriidae). Great Lks Entomol 16:143-148

Elkinton JS, Liebhold AM (1990) Population dynamics of gypsy moth in North America. Annu Rev Entomol 35:571-596

Fisher RA (1937) The wave of advance of advantageous genes. Ann Eugenics 7:355-369

Frank KL, Geils BW, Kalkstein LS, Thistle HW Jr (2008) Synoptic climatology of the long-distance dispersal of white pine blister rust II. Combination of surface and upper-level conditions. Int $\mathrm{J}$ Biomoeteorol 52:653-666

Geils BW, Conklin D, Frank K, Guyon J, Harris JL, Hoffman J, Jacobi W, Kearns H, Newcomb M, Smith E, Van Arsdel E, Vogler D (2003) New information on the distribution of white pine blister rust for 2002. In: Stone J, Maffei H (comps) Proceedings of the 50th Western International Forest Disease Work Conference, 7-11 October 2002, Powell River, Be. Bend, OR, US Department of Agriculture, Forest Service, Central Oregon Service Center, pp 94-99

Gray DR, Ravlin FW, Régnière J, Logan JA (1995) Further advances toward a model of gypsy moth (Lymantria dispar (L.)) egg phenology: respiration rates and thermal responsiveness during diapause, and age-dependent developmental rates in postdiapause. J Insect Physiol 41:247-256

Hajek AE, Tobin PC (2009) North American eradications of Asian and European gypsy moth. In: Hajek AE, Glare TR, O'Callaghan M (eds) Use of microbes for control and eradication of invasive arthropods. Springer, Dordrecht, pp 71-89

Hengeveld R (1989) Dynamics of biological invasions. Chapman and Hall, London

Hulme PE, Bacher S, Kenis M, Klotz S, Kühn I, Minchin D, Nentwig W, Olenin S, Panov V, Pergl J, Pyšek P, Roques A, Sol D, Solarz W, Vilà M (2008) Grasping at the routes of biological invasions: a framework for integrating pathways into policy. J Appl Ecol 45:403-414

Isard SA, Gage SH (2001) Flow of life in the atmosphere. Michigan State University Press, East Lansing

Isard SA, Gage SH, Comtois P, Russo JM (2005) Principles of the atmospheric pathway for invasive species applied to soybean rust. Bioscience 55:851-861

Isard SA, Mortensen DA, Fleischer SJ, DeWolf ED (2009) Application of aerobiology to IPM. In: Ratcliff EB, Hutchison WD, Cancelado RE (eds) Integrated pest management. Concepts, Tactics, Strategies and Case Studies. Cambridge University Press, Cambridge, pp 90-106

Krause SC, Walker MA, Klonowski J, Clemens NS (1994) Gypsy moth in Wisconsin - 1994. In: Hilburn DJ, Johnson KJR, Mudge AD (eds) Proceedings of the annual gypsy moth review. Oregon Department of Agriculture, Salem, OR, pp 351-356
Levine JM, D'Antonio CM (2003) Forecasting biological invasions with increasing international trade. Conserv Biol 17:322-326

Liebhold AM, Tobin PC (2006) Growth of newly established alien populations: comparison of North American gypsy moth colonies with invasion theory. Popul Ecol 48:253-262

Liebhold AM, Mastro VC, Schaefer PW (1989) Learning from the legacy of Léopold Trouvelot. Bull Entomol Soc Am 35:20-22

Liebhold AM, Gottschalk KW, Muzika RM, Montgomery ME, Young R, O'Day K, Kelley B (1995) Suitability of North American tree species to the gypsy moth: a summary of field and laboratory tests. USDA Forest Service General Technical Report NE-211, Radnor, PA

Lockwood JL, Hoopes M, Marchetti M (2007) Invasion ecology. Blackwell, Malden

Mack RN, Simberloff D, Lonsdale WM, Evans H, Clout M, Bazzaz FA (2000) Biotic invasions: causes, epidemiology, global consequences, and control. Ecol Appl 10:689-710

Mason CJ, McManus ML (1981) Larval dispersal of the gypsy moth. In: Doane CC, McManus ML (eds) The gypsy moth: research toward integrated pest management. USDA Forest Service Technical Bulletin 1584, pp 161-202

Michigan State University (2011) Michigan Automated Weather Network. http://www.agweather.geo.msu.edu/mawn/. Accessed 26 March 2011

McCullough DG, Work TT, Cavey JF, Liebhold AM, Marshall D (2006) Interceptions of nonindigenous plant pests at US ports of entry and border crossings over a 17-year period. Biol Invasions 8:611-630

McManus ML, Mason CJ (1983) Determination of the settling velocity and its significance to larval dispersal of the gypsy moth (Lepidoptera: Lymantriidae). Environ Entomol 12:270-272

Mooney HA, Cleland EE (2001) The evolutionary impact of invasive species. Proc Natl Acad Sci USA 98:5446-5451

Morin RS, Liebhold AM, Luzader ER, Lister AJ, Gottschalk KW, Twardus DB (2005) Mapping host-species abundance of three major exotic forest pests. USDA Res Paper NE-726, USDA Forest Service, Newtown Square, PA

Parker IM, Simberloff D, Lonsdale WM, Goodell K, Wonham M, Kareiva PM, Williamson MH, Von Holle B, Moyle PB, Byers JE, Goldwasser L (1999) Impact: toward a framework for understanding the ecological effects of invaders. Biol Invasions 1:3-19

R Development Core Team (2011) The R Project for Statistical Computing. www.r-project.org. Accessed 26 March 2011

Régnière J, Sharov A (1998) Phenology of Lymantria dispar (Lepidoptera: Lymantriidae), male flight and the effect of moth dispersal in heterogeneous landscapes. Int J Biometeorol 41:161-168

Sharov AA, Liebhold AM (1998) Model of slowing the spread of the gypsy moth (Lepidoptera: Lymantriidae) with a barrier zone. Ecol Appl 8:1170-1179

Sharov AA, Liebhold AM, Ravlin FW (1995) Prediction of gypsy moth (Lepidoptera: Lymantriidae) mating success from pheromone trap counts. Environ Entomol 24:1239-1244

Sharov AA, Liebhold AM, Roberts EA (1997) Methods for monitoring the spread of gypsy moth (Lepidotperta: Lymantriidae) populations in the Appalachian Mountains. J Econ Entomol 90:1259-1266

Shigesada N, Kawasaki K (1997) Biological invasions: theory and practice. Oxford University Press, New York

Skellam JG (1951) Random dispersal in theoretical populations. Biometrika 38:196-218

Taylor CM, Hastings A (2005) Allee effects in biological invasions. Ecol Lett 8:895-908

Tcheslavskaia K, Brewster CC, Sharov AA (2002) Mating success of gypsy moth (Lepidoptera: Lymantriidae) females in southern Wisconsin. Great Lks Entomol 35:1-7 
Tobin PC, Blackburn LM (eds) (2007) Slow the Spread: a national program to manage the gypsy moth. Gen. Tech. Rep. NRS-6, US Dept Agric For Serv, Newtown Square

Tobin PC, Blackburn LM (2008) Long-distance dispersal of the gypsy moth (Lepidoptera: Lymantriidae) facilitated its initial invasion of Wisconsin. Environ Entomol 37:87-93

Tobin PC, Liebhold AM, Roberts EA (2007) Comparison of methods for estimating the spread of a nonindigenous species. J Biogeogr 34:305-312

Tobin PC, Klein KT, Leonard DS (2009a) Gypsy moth (Lepidoptera: Lymantriidae) flight behavior and phenology based upon field-deployed automated pheromone-baited traps. Environ Entomol 38:1555-1562

Tobin PC, Robinet C, Johnson DM, Whitmire SL, Bjørnstad ON, Liebhold AM (2009b) The role of Allee effects in gypsy moth, Lymantria dispar (L.), invasions. Popul Ecol 51:373-384

Venette RC, Ragsdale DW (2004) Assessing the invasion by soybean aphid (Homoptera: Aphididae): where will it end? Ann Entomol Soc Am 97:219-226

Whitmire SL, Tobin PC (2006) Persistence of invading gypsy moth populations in the United States. Oecologia 147:230-237 


\begin{tabular}{|c|c|c|c|}
\hline \multicolumn{4}{|c|}{ Appendix 2 The 66 favorable transport periods identified by the algorithm ${ }^{1}$} \\
\hline Dates & \begin{tabular}{|c|}
$\begin{array}{c}\text { Number of } \\
\text { hourly events }\end{array}$ \\
\end{tabular} & $\begin{array}{l}\text { Sum of weights } \\
\text { of hourly events }\end{array}$ & Primary source-target pairs where event occurred \\
\hline $5 / 24 / 1996$ & 6 & 2.17 & West Olive-Milwaukee \\
\hline $5 / 28-29 / 1996$ & 17 & 6.48 & $\begin{array}{l}\text { West Olive-Milwaukee } \\
\text { Arlene-Milwaukee }\end{array}$ \\
\hline $5 / 25-27 / 1997$ & 42 & 15.54 & \begin{tabular}{|l} 
Hart-Madison \\
Hart-Milwaukee \\
Benzonia-Milwaukee \\
Hudsonville - Madison \\
Hudsonville - Milwaukee
\end{tabular} \\
\hline $6 / 1-3 / 1997$ & 7 & 2.16 & $\begin{array}{l}\text { Hart - Madison } \\
\text { Hart - Milwaukee }\end{array}$ \\
\hline $6 / 7-8 / 1997$ & 17 & 2.88 & $\begin{array}{l}\text { Hart - Madison } \\
\text { Hudsonville - Milwaukee }\end{array}$ \\
\hline 8/10-11/1997 & 13 & 4.04 & $\begin{array}{l}\text { Hart - Milwaukee } \\
\text { Benzonia - Milwaukee }\end{array}$ \\
\hline $5 / 7-9 / 1998$ & 40 & 15.57 & $\begin{array}{l}\text { Hart-Madison } \\
\text { Hart-Milwaukee } \\
\text { Benzonia-Milwaukee }\end{array}$ \\
\hline 7/31-8/1/1998 & 2 & 0.29 & Hart - Milwaukee \\
\hline $4 / 27-29 / 1999$ & 57 & 4.94 & \begin{tabular}{|l} 
Hart-Madison \\
Hart-Milwaukee \\
Hudsonville-Madison \\
Hudsonville-Milwaukee \\
Benzonia-Milwaukee
\end{tabular} \\
\hline $5 / 13 / 1999$ & 12 & 4.78 & $\begin{array}{l}\text { Hart-Madison } \\
\text { Hart-Milwaukee }\end{array}$ \\
\hline $5 / 22 / 1999$ & 9 & 2.24 & $\begin{array}{l}\text { Hart - Milwaukee } \\
\text { Benzonia - Milwaukee }\end{array}$ \\
\hline $4 / 21 / 2000$ & 4 & 0.27 & Hart - Milwaukee \\
\hline $4 / 24 / 2000$ & 1 & 0.07 & Hart-Madison \\
\hline $5 / 19 / 2000$ & 5 & 1.15 & Hart-Milwaukee \\
\hline $7 / 28 / 2000$ & 18 & 2.69 & $\begin{array}{l}\text { Hart - Madison } \\
\text { Hart - Milwaukee }\end{array}$ \\
\hline $4 / 29 / 2001$ & 1 & 0.07 & Green Bay - Madison \\
\hline $5 / 14 / 2001$ & 1 & 0.36 & Green Bay - Madison \\
\hline $5 / 16 / 2001$ & 4 & 1.58 & Milwaukee - Madison \\
\hline $5 / 20 / 2001$ & 7 & 2.53 & $\begin{array}{l}\text { Milwaukee - Green Bay } \\
\text { Green Bay - Madison }\end{array}$ \\
\hline $5 / 26 / 2001$ & 1 & 0.17 & Milwaukee - Madison \\
\hline $5 / 31 / 2001$ & 1 & 0.07 & Milwaukee - Madison \\
\hline $7 / 18 / 2001$ & 1 & 0.11 & Milwaukee - Madison \\
\hline
\end{tabular}




\begin{tabular}{|c|c|c|c|}
\hline $7 / 24-27 / 2001$ & 52 & 13.74 & \begin{tabular}{|l} 
Milwaukee - Green Bay \\
Milwaukee - Madison \\
Hart - Madison \\
Hart - Milwaukee \\
Hudsonville - Madison \\
Hudsonville - Milwaukee \\
Green Bay - Madison \\
\end{tabular} \\
\hline $7 / 30-31 / 2001$ & 6 & 1.30 & $\begin{array}{l}\text { Green Bay - Madison } \\
\text { Milwaukee - Madison }\end{array}$ \\
\hline $8 / 16 / 2001$ & 3 & 0.30 & Green Bay - Milwaukee \\
\hline $8 / 18 / 2001$ & 1 & 0.35 & Escanaba - Green Bay \\
\hline $5 / 8 / 2002$ & 1 & 0.25 & Milwaukee - Madison \\
\hline $5 / 11-12 / 2002$ & 18 & 4.97 & $\begin{array}{l}\text { Green Bay-Madison } \\
\text { Milwaukee-Green Bay } \\
\text { Milwaukee-Madison }\end{array}$ \\
\hline $5 / 19 / 2002$ & 6 & 2.03 & Milwaukee - Madison \\
\hline $5 / 21 / 2002$ & 1 & 0.38 & Milwaukee - Green Bay \\
\hline $7 / 19 / 2002$ & 1 & 0.14 & Milwaukee - Madison \\
\hline $7 / 23-24 / 2002$ & 17 & 4.02 & $\begin{array}{l}\text { Hudsonville - Madison } \\
\text { Hudsonville - Milwaukee } \\
\text { Milwaukee - Madison }\end{array}$ \\
\hline $8 / 5-6 / 2002$ & 9 & 2.67 & Hart - Milwaukee \\
\hline $5 / 2-3 / 2003$ & 8 & 1.06 & $\begin{array}{l}\text { Hart - Milwaukee } \\
\text { Milwaukee - Madison }\end{array}$ \\
\hline $5 / 8-9 / 2003$ & 10 & 2.58 & Milwaukee - Madison \\
\hline $5 / 15-16 / 2003$ & 2 & 0.77 & Milwaukee - Madison \\
\hline $5 / 18 / 2003$ & 7 & 2.74 & Milwaukee - Madison \\
\hline $5 / 21-22 / 2003$ & 7 & 2.67 & Milwaukee - Madison \\
\hline $5 / 25 / 2003$ & 2 & 0.64 & Milwaukee - Madison \\
\hline $7 / 27 / 2003$ & 2 & 0.59 & Milwaukee - Madison \\
\hline $8 / 11 / 2003$ & 16 & 6.00 & \begin{tabular}{|l} 
Hart - Madison \\
Hart - Milwaukee
\end{tabular} \\
\hline $8 / 19 / 2003$ & 2 & 0.25 & Green Bay - Madison \\
\hline $5 / 6 / 2004$ & 3 & 0.75 & Hart - Milwaukee \\
\hline $5 / 11 / 2004$ & 1 & 0.14 & Green Bay - Madison \\
\hline $5 / 19 / 2004$ & 4 & 1.20 & Milwaukee - Madison \\
\hline $5 / 24 / 2004$ & 4 & 0.62 & Milwaukee - Madison \\
\hline $7 / 23-24 / 2004$ & 5 & 1.55 & Milwaukee - Madison \\
\hline $8 / 18-19 / 2004$ & 8 & 3.12 & Green Bay - Milwaukee \\
\hline $8 / 25 / 2004$ & 2 & 0.64 & Green Bay - Madison \\
\hline $8 / 31-9 / 1 / 2004$ & 3 & 0.64 & Escanaba-Green Bay \\
\hline $9 / 8 / 2004$ & 7 & 2.68 & $\begin{array}{l}\text { Escanaba - Green Bay } \\
\text { Escanaba - Milwaukee }\end{array}$ \\
\hline $4 / 20-21 / 2005$ & 6 & 0.63 & $\begin{array}{l}\text { Hart - Milwaukee } \\
\text { Milwaukee - Madison }\end{array}$ \\
\hline $5 / 17 / 2005$ & 5 & 1.56 & Milwaukee - Green Bay \\
\hline $5 / 20 / 2005$ & 5 & 1.26 & Hart - Milwaukee \\
\hline $5 / 31 / 2005$ & 1 & 0.06 & Milwaukee - Madison \\
\hline $6 / 3 / 2005$ & 1 & 0.14 & Green Bay - Madison \\
\hline
\end{tabular}




\begin{tabular}{|c|c|c|c|}
\hline $7 / 11 / 2005$ & 7 & 0.84 & $\begin{array}{l}\text { Hudsonville - Milwaukee } \\
\text { Milwaukee - Madison }\end{array}$ \\
\hline $7 / 14-15 / 2005$ & 5 & 1.77 & $\begin{array}{l}\text { Hudsonville - Milwaukee } \\
\text { Milwaukee - Madison }\end{array}$ \\
\hline $4 / 25 / 2006$ & 2 & 0.16 & Hart - Milwaukee \\
\hline $4 / 28 / 2006$ & 3 & 0.38 & $\begin{array}{l}\text { Milwaukee - Green Bay } \\
\text { Milwaukee - Madison }\end{array}$ \\
\hline $7 / 18 / 2006$ & 1 & 0.11 & Milwaukee - Madison \\
\hline $8 / 10 / 2006$ & 8 & 2.90 & $\begin{array}{l}\text { Escanaba-Green Bay } \\
\text { Escanaba-Milwaukee }\end{array}$ \\
\hline $5 / 3-6 / 2007$ & 52 & 12.45 & \begin{tabular}{|l} 
Hart-Madison \\
Green Bay-Madison \\
Milwaukee-Green Bay \\
Milwaukee-Madison
\end{tabular} \\
\hline $5 / 28 / 2007$ & 2 & 0.29 & Escanaba - Green Bay \\
\hline $7 / 20 / 2007$ & 2 & 0.77 & Green Bay - Madison \\
\hline $7 / 27-28 / 2007$ & 9 & 1.33 & $\begin{array}{l}\text { Hart - Milwaukee } \\
\text { Milwaukee - Madison }\end{array}$ \\
\hline
\end{tabular}

